\title{
Analisis Dampak Lingkungan dari Perusahaan Jasa Konstruksi di Surabaya dengan Software SimaPro
}

\author{
Kelvin \\ Departemen Teknik Industri, Institut Sains dan Teknologi Terpadu Surabaya \\ E-mail: kelvin@stts.edu
}

\begin{abstract}
Abstrak- Perusahaan jasa konstruksi merupakan perusahaan yang bergerak di bidang pembangunan infrastruktur, sarana, dan prasarana fisika. Dalam pelaksanaannya perusahaan konstruksi menggunakan berbagai jenis material alam yang dapat menimbulkan dampak terhadap lingkungan. Tujuan dari penelitian ini adalah untuk menilai dampak lingkungan yang dihasilkan dari perusahaan konstruksi serta melakukan perbaikan guna menurunkan dampak lingkungan. Untuk itu dipilihlah salah satu produk yang dihasilkan oleh perusahaan jasa konstruksi yaitu produk railing. Dimana produk railing merupakan produk konstruksi pendukung bangunan yang memiliki fungsi sebagai pembatas bangunan dengan bahan utama berupa material besi. Untuk dapat menghasilkan produk tersebut, diperlukan tahapan proses yang dimana setiap tahapan proses tersebut akan memberikan dampak terhadap lingkungan yang tidak dapat terlihat secara langsung. Dampak lingkungan tersebut dapat berupa pengaruh terhadap kesehatan manusia, ekosistem, dan sumber daya alam. Untuk itu dalam penelitian ini, dilakukan perbaikan produk dengan cara mengganti material dan desain untuk mengurangi dampak lingkungan yang dihasilkan dengan dasar metode Design for Environment (DFE), serta penilaian dampak lingkungan dari produk sebelum dan setelah perbaikan dengan metode Life Cycle Assessment (LCA). Hasil yang didapatkan dari perbaikan produk railing pada penelitian ini adalah mampu mengurangi dampak lingkungan, dengan rincian $60,2 \%$ untuk dampak kesehatan manusia, 65,8\% untuk dampak ekosistem, dan $53,2 \%$ untuk dampak sumber daya alam.
\end{abstract}

Kata Kunci- Dampak lingkungan, Design for Environment, Life Cycle Assessment, SimaPro.

\section{Pendahuluan}

$\mathrm{S}$ umber daya alam adalah semua material yang diperoleh dari alam, baik berupa unsur hayati maupun nonhayati dan dimanfaatkan oleh manusia untuk memenuhi kebutuhan dan kesejahteraan hidupnya [1]. Kebutuhan sumber daya alam berbanding lurus dengan pertumbuhan jumlah penduduk, dimana semakin meningkat jumlah penduduk, maka kebutuhan akan sumber daya alam untuk kebutuhan hidup akan semakin meningkat. Eksploitasi

Naskah Masuk : : 9 November 2021

Naskah Direvisi : 22 November 2021

Naskah Diterima : 23 November 2021 terhadap sumber daya alam ini, dapat menyebabkan dampak kerusakan lingkungan berupa penurunan mutu sumber daya hayati, hingga perubahan iklim yang dapat mempengaruhi keberlangsungan hidup makhluk hidup [2].

Perusahaan jasa konstruksi merupakan salah satu jenis industri hilir yang berperan penting dalam pembangunan serta memanfaatkan berbagai sumber daya alam nonhayati [3]. Sumber daya alam utama yang banyak digunakan dalam konstruksi adalah material besi. Pemanfaatan material besi dalam konstruksi sangatlah banyak, karena karakteristik besi yang kuat, mudah untuk diproses, serta mudah diperoleh [4]. Salah satu pemanfaatan material besi dalam konstruksi adalah untuk pembuatan produk railing. Railing merupakan salah satu jenis konstruksi pendukung bangunan yang memiliki arti pagar pembatas. Produk railing sering dimaanfaatkan sebagai pagar pembatas pada tangga, balkon, dan pembatas sisi pada lantai atas yang terbuka.

Dalam siklus hidup produk railing, menghasilkan berbagai macam dampak terhadap lingkungan. Salah satunya dalam tahap produksinya, dimana produk railing memberikan dampak terhadap lingkungan berupa gangguan kesehatan yang diakibatkan oleh fume (asap) yang mengandung logam berat dan gas karbon monoksida (CO) [5]. Selain itu, pada tahap pendistribusian produk railing yang juga menyumbang pemanasan global akibat gas emisi buangan alat transportasi yang mengandung karbondioksida (CO2).

Berdasarkan ISO 14040/44 dampak lingkungan yang ditimbulkan dari produk dapat menyebabkan kerugian lingkungan berupa gangguan terhadap kesehatan manusia, penurunan kualitas lingkungan, dan deplesi sumber daya alam [5]. Oleh sebab itu, dalam penelitian ini dilakukan Life Cycle Assessment dan perbaikan produk untuk dapat menekan dampak lingkungan yang ditimbulkan dari pembuatan produk railing

\section{LANDASAN TEORI}

\section{A. Life Cycle Assessment (LCA)}

Life Cycle Assessment merupakan suatu pendekatan "cradle-to-grave" untuk menilai sistem yang ada dalam dunia industri, dimana "Cradle-to-grave" adalah pendekatan yang diawali dari pengambilan material yang bersumber dari alam alam untuk membuat sebuah produk dan berakhir ketika bahan tersebut dikembalikan ke alam [6]. Melalui proses LCA memungkinkan untuk menilai dampak 
lingkungan yang dihasilkan dari semua tahap dalam siklus hidup suatu produk, termasuk dampak yang sering terlewatkan dalam analisis dengan metode tradisional. Contohnya seperti dampak ekstraksi material, transportasi, dan pembuangan limbah. LCA mampu memberikan pandangan yang lebih komprehensif mengenai aspek lingkungan dari produk atau proses yang ada. LCA memiliki pendekatan yang bertahap dan sistematis terdiri dari empat fase yang dapat dijelaskan melalui gambar 1 berikut [7]:

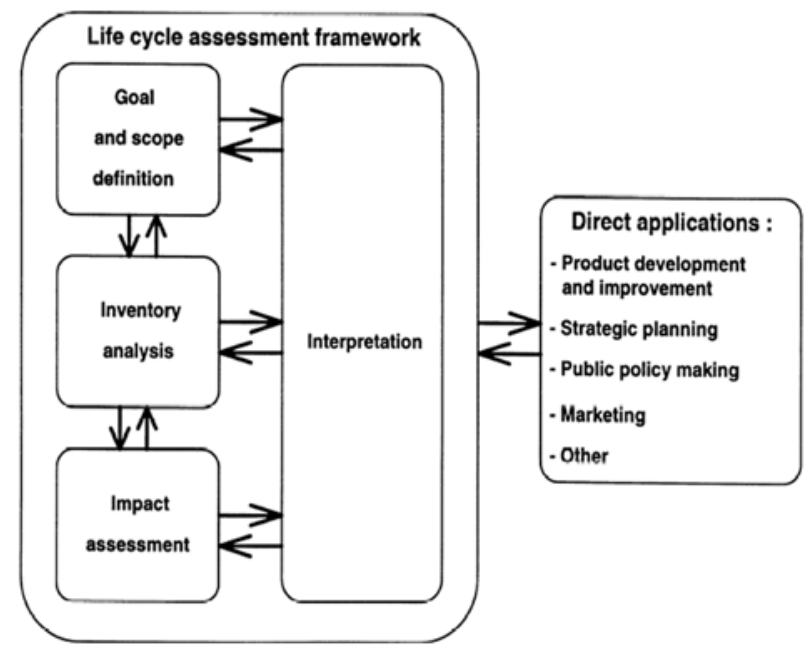

Gambar 1. LCA Phases Framework

\section{B. Design for Environment (DFE)}

Design for Environment adalah metode sistematis untuk mereduksi atau mengeliminasi dampak lingkungan yang dihasilkan pada seluruh siklus hidup produk yang dimulai dari proses ekstraksi material hingga proses pembuangannya [8]. Dalam penerapannya DFE mempertimbangkan dampak lingkungan, kesehatan, keselamatan, dan keberlangsungan sumber daya berdasarkan desain dari produk.

Berdasarkan objektif utama dan orientasinya pada siklus hidup produk, DFE dapat digolongkan menjadi dua aspek sebagai berikut:

- The double level of intevention, hal ini menjelaskan bahwa cakupan yang dapat dianalisis dengan pendekatan DFE adalah dalam lingkup produk dan proses.

- Proactive action of intervention, aspek yang didasarkan pada anggapan bahwa efisiensi terbesar ada pada proses pengembangan produk.

\section{SimaPro}

SimaPro adalah sebuah software yang dapat digunakan untuk melakukan penilaian dampak lingkungan dengan pendekatan LCA [9]. Keunggulan utama Simapro adalah dapat menerapkan berbagai aplikasi LCA, seperti pelaporan keberlanjutan, analisa jejak karbon dan air, proses desain produk, pembuatan produk ramah lingkungan, dan penentu indikator kinerja utama. Selain itu, keuggulan lainnya yang diperoleh dari SimaPro adalah sebagai berikut [10]:

- Mampu memodelkan dan menganalisis siklus hidup produk yang kompleks dengan cara yang sistematis dan transparan.

- $\quad$ Mampu mengukur dampak lingkungan dari produk dan layanan di seluruh tahap siklus hidup produk.
- Mampu mengidentifikasi informasi-informasi penting yang saling bertautan dalam rantai pasok, mulai dari ekstraksi bahan baku hingga akhir umur produk.

- Dilengkapi dengan beragam database inventori yang up to date, diantaranya: Agri-footprint, Ecoinvent database, U.S. Life Cycle Inventory database, Swiss Input/Output database, Industry data library: Plastics Europe, ERASM, Worldsteel.

- Memiliki berbagai metode analisis LCA pendukung, diantaranya: Impact 2002+, TRACI 2.1, ReCiPe 2016, Ecosistem Damage Potential, Greenhouse Gas Protocol, dan Cummulative Energy Demand.

\section{METODOLOGI PENELITIAN}

\section{A. Tahap Persiapan}

Pada tahap ini ditentukan objek penelitian berupa produk railing dari perusahaan jasa konstruksi, dan menentukan metode yang akan digunakan dalam penelitian yaitu, LCA, DFE, serta penggunaan software Simapro untuk melakukan proses analisis.

\section{B. Tahap Pengumpulan Data}

Pada tahap ini dilakukan proses pengumpulan data untuk digunakan dalam analisis. Adapun data yang harus dikumpulkan adalah gambar desain railing, alur proses pembuatan railing, bahan yang diperlukan dalam proses pembuatan railing, serta data lainnya yang dibutuhkan dalam proses analisis.

\section{Tahap Analisis dan Pengolahan Data}

Pada tahap ini proses analisis dan pengolahan data yang dilakukan adalah sebagai berikut:

- Penilaian terhadap dampak lingkungan menggunakan SimaPro.

- Merancang desain produk berdasarkan DFE untuk memperoleh alternatif produk dengan nilai dampak lingkungan yang lebih rendah.

- Penilaian ulang terhadap hasil perbaikan dan melakukan komparasi nilai dampak lingkungan pada siklus produk sebelum dan sesudah perbaikan menggunakan perangkat lunak SimaPro.

\section{Tahap Akhir}

Pada tahap akhir ini dilakukan penarikan kesimpulan hasil dampak lingkungan yang dihasilkan dengan membandingkan produk awal dengan produk setelah rancang ulang. Berikut pada gambar 2 adalah flowchart metodologi penelitian dapat: 


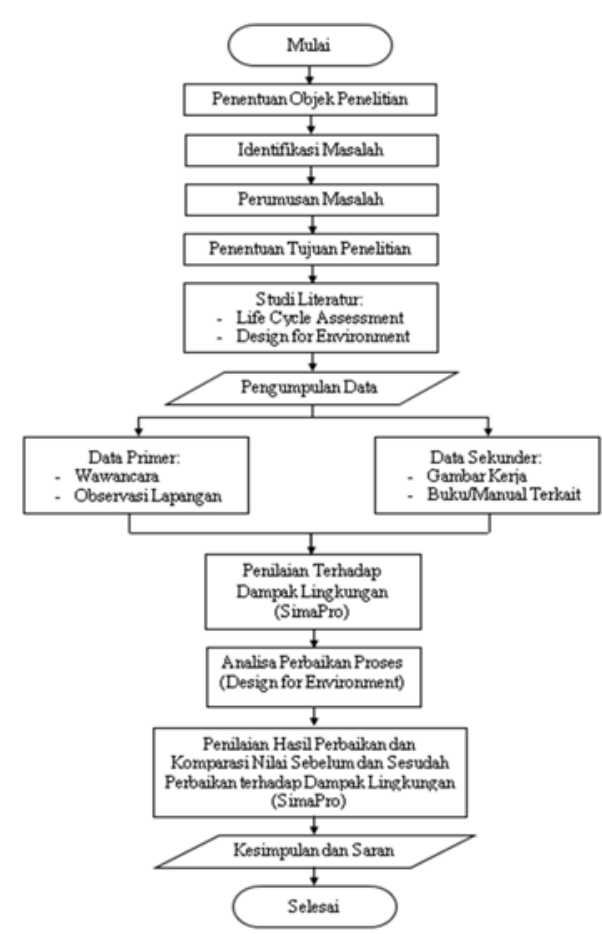

Gambar 2. Flowchart Metodologi Penelitian

\section{Pengumpulan Data}

\section{A. Spesifikasi Produk Railing}

Spesifikasi produk meliputi bahan material penyusun produk, gambar dan imensi produk, komponen produk, serta proses pembuatan produk. Berikut pada gambar 3 adalah gambar kerja untuk produk railing yang digunakan dalam penelitian ini.

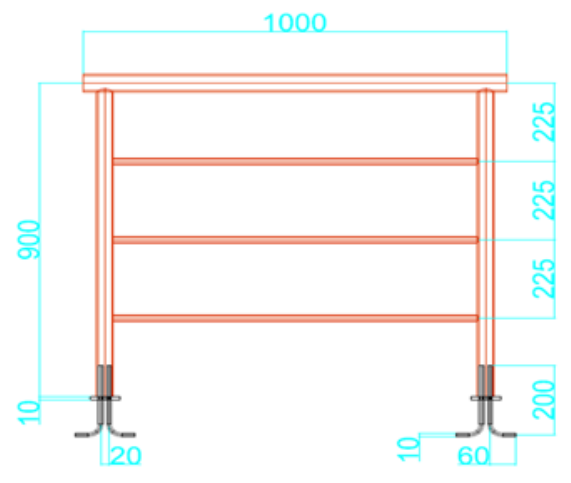

Gambar 3. Gambar Kerja Produk Railing

Sedangkan untuk komponen penyusun produk railing dapat dilihat pada tabel 1 part list di bawah ini.

TABEL I

PART LIST PRODUK RAILING

\begin{tabular}{|l|l|c|l|c|c|c|c|}
\hline \multirow{2}{*}{ Part Code } & \multirow{2}{*}{$\begin{array}{c}\text { Nama } \\
\text { Part }\end{array}$} & \multirow{2}{*}{$\begin{array}{c}\text { Jumlah } \\
\text { /Unit }\end{array}$} & \multirow{2}{*}{ Material } & \multicolumn{3}{|c|}{ Ukuran (mm) } & \multirow{2}{*}{$\begin{array}{c}\text { Massa/ } \\
\text { Unit }\end{array}$} \\
\cline { 5 - 7 } HR-001 & Hand Rail & 1 & $\begin{array}{l}\text { Pipa Besi } \\
\text { SNI Light }\end{array}$ & 50 & 925 & 3,91 & 4,080 \\
\hline PV-002 & $\begin{array}{l}\text { Pipa } \\
\text { Vertikal }\end{array}$ & 2 & $\begin{array}{l}\text { Pipa Besi } \\
\text { SNI Light }\end{array}$ & 40 & 900 & 3,68 & 2,907 \\
\hline PH-003 & $\begin{array}{l}\text { Pipa } \\
\text { Horizontal }\end{array}$ & 3 & $\begin{array}{l}\text { Pipa Besi } \\
\text { SNI Light }\end{array}$ & 20 & 825 & 2,87 & 1,139 \\
\hline PK-004 & Plat Kaki & 2 & Plat Besi & 70 & - & 10 & 0,5793 \\
\hline AK-005 & Angkur & 2 & $\begin{array}{l}\text { Rebar } \\
\text { (Besi } \\
\text { Beton) }\end{array}$ & 10 & 260 & - & 0,3204 \\
\hline
\end{tabular}

\section{B. Proses Produksi Railing}

Dalam pembuatan produk railing diperlukan beberapa proses diantaranya proses pembuatan tiap komponen produk, tahap perakitan, dan tahap finising. Tahapan proses dari setiap pembuatan komponen serta bahan yang digunakan secara detail dapat dilihat melalui route sheet railing pada tabel 2 berikut ini.

TABEL II

ROUTE SHEET PRODUK RAILING

\begin{tabular}{|c|c|c|c|c|c|c|}
\hline $\begin{array}{l}\text { No. } \\
\text { Operasi }\end{array}$ & $\begin{array}{c}\text { Deskripsi } \\
\text { Proses }\end{array}$ & Jenis Mesin & $\begin{array}{c}\text { Peralatan } \\
\text { dan Bahan } \\
\text { Pendukung }\end{array}$ & $\begin{array}{c}\text { Departeme } \\
\text { n }\end{array}$ & $\begin{array}{l}\text { Waktu } \\
\text { Proses } \\
\text { (menit) }\end{array}$ & $\begin{array}{l}\text { Deskripsi } \\
\text { Material }\end{array}$ \\
\hline 1001 & Pengelasan & $\begin{array}{l}\text { Alat las Oxy- } \\
\text { Acetylene }\end{array}$ & Kawat Besi & Produksi & 10 & \multirow{7}{*}{ Mild Steel } \\
\hline 1002 & $\begin{array}{l}\text { Penghalusa } \\
\text { n Hasil Las }\end{array}$ & $\begin{array}{l}\text { Gerinda } \\
\text { Tangan }\end{array}$ & $\begin{array}{l}\text { Wheel Disk } \\
\text { 100x 10x16 } \\
\text { mm }\end{array}$ & Produksi & 1 & \\
\hline 1003 & $\begin{array}{c}\text { Pembersiha } \\
\mathrm{n}\end{array}$ & - & $\begin{array}{l}\text { Bensin, } \\
\text { Kain } \\
\text { Majun, } \\
\text { Amplas, Air }\end{array}$ & Produksi & 25 & \\
\hline 1004 & $\begin{array}{l}\text { Pengecatan } \\
\text { Tahap } \\
\text { Dasar }\end{array}$ & Kompresor & Epoxy & Produksi & 10 & \\
\hline 1005 & $\begin{array}{c}\text { Pengecatan } \\
\text { Tahap } \\
\text { Akhir }\end{array}$ & Kompresor & Cat NC & Produksi & 10 & \\
\hline 1006 & Inspeksi & - & - & Produksi & 1 & \\
\hline 1007 & $\begin{array}{c}\text { Pengemasa } \\
n\end{array}$ & - & $\begin{array}{l}\text { Lakban, } \\
\text { Karton }\end{array}$ & Pengiriman & 15 & \\
\hline
\end{tabular}

Untuk proses perakitan produk dapat dilihat melalui gambar 4 Assembly Chart produk railing di bawah ini.

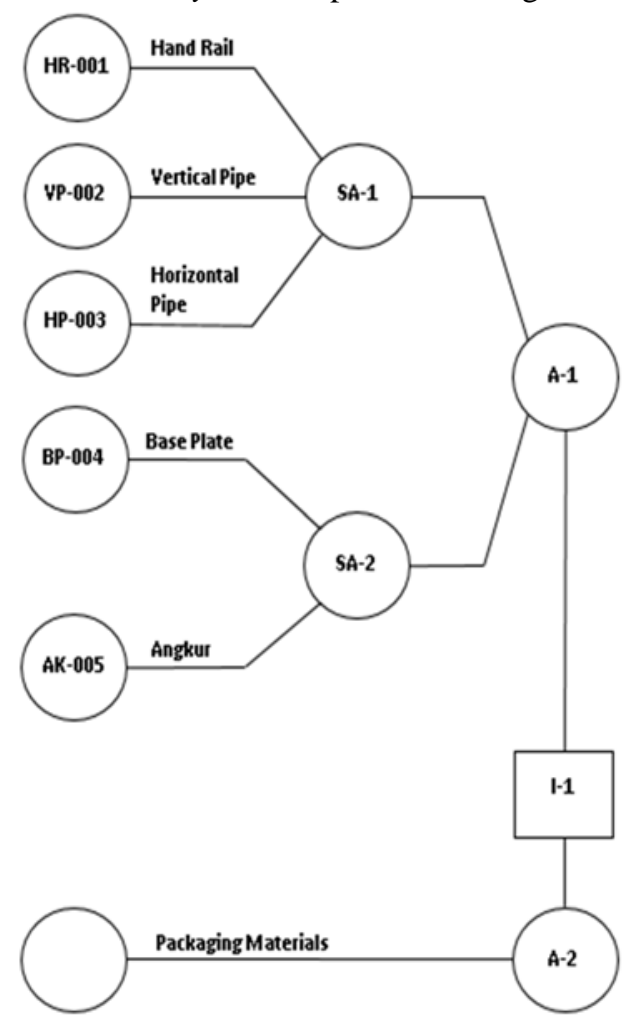

Gambar 4. Assembly Chart Produk Railing

Sedangkan untuk tahapan proses pembuatan produk railing secara detail dari tahap awal hingga produk jadi dapat dilihat melalui gambar 5 Operational Process Chart (OPC) berikut ini: 


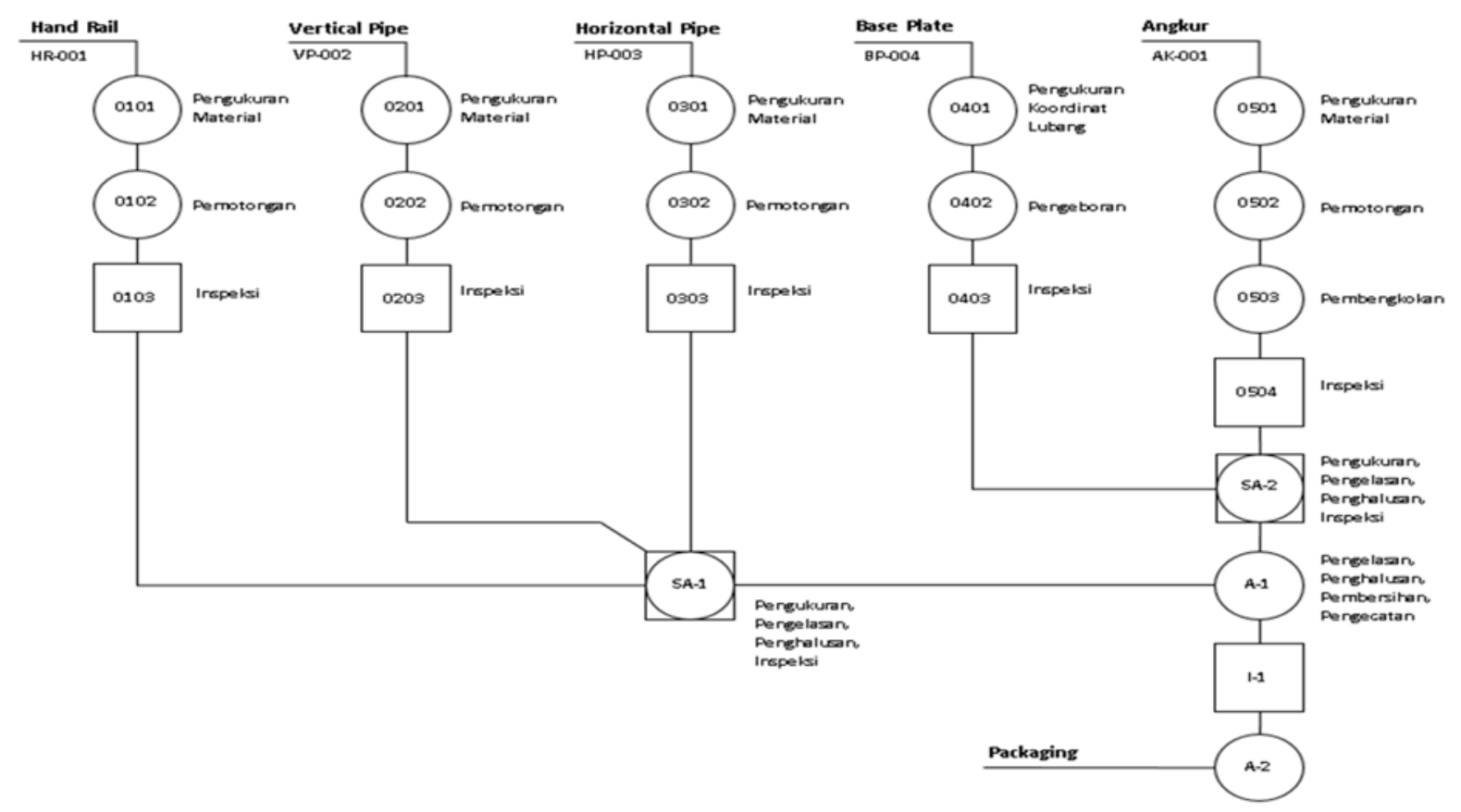

Gambar. 5. Operational Process Chart Produk Railing

\section{Peralatan, Transportasi, dan Material Pendukung}

Peralatan, alat transportasi, dan material pendukung yang digunakan dalam proses produksi railing perlu diperhatikan karena termasuk komponen yang menyumbang besarnya nilai dampak lingkungan. Hal ini dapat terjadi karena dalam proses LCA semua input yang berkaitan dengan pembuatan produk perlu didefinisikan secara detail,

Peralatan dalam penelitian ini merujuk pada mesin atau peralatan lain yang menggunakan energi berupa listrik untuk beroperasi. Sedangkan alat transportasi yang digunakan untuk mengangkut bahan baku dan produk jadi railing adalah mobil bak terbuka. Data yang digunakan dari alat transportasi adalah jarak tempuh alat transportasi yang berkaitan dengan produksi railing. Sedangkan, untuk material pendukung berupa bahan habis pakai ataupun bahan yang melekat pada material utama produk, seperti abrasive wheel yang digunakan untuk mata pisau gerinda potong, air, dan amplas.

\section{Analisis Dan Pengolahan Data}

\section{A. Penilaian Dampak Lingkungan Sebelum Perbaikan}

Produk yang akan dinilai pada tahap awal adalah Railing A. Railing A merupakan produk railing yang diproduksi oleh industri konstruksi. Proses penilaian dilakukan pada software Simapro dan didapatkan hasil untuk produk railing A adalah sebesar 8,32 E-5 DALY untuk kategori kesehatan manusia, sebesar 2,64 E-7 species.year untuk kategori kerusakan ekosistem, dan sebesar 1,97 USD 2013 untuk kategori kerusakan sumber daya alam. dampak lingkungan terbesar disumbang oleh bahan utama pembuatan produk. Oleh sebab itu, perbaikan difokuskan pada perancangan desain yang lebih efisien terutama dalam penggunaan jumlah bahan baku utama serta jenis bahan baku utama yang digunakan dalam produk railing. Secara lebih detail dapat dilihat pada gambar 6 di bawah ini.

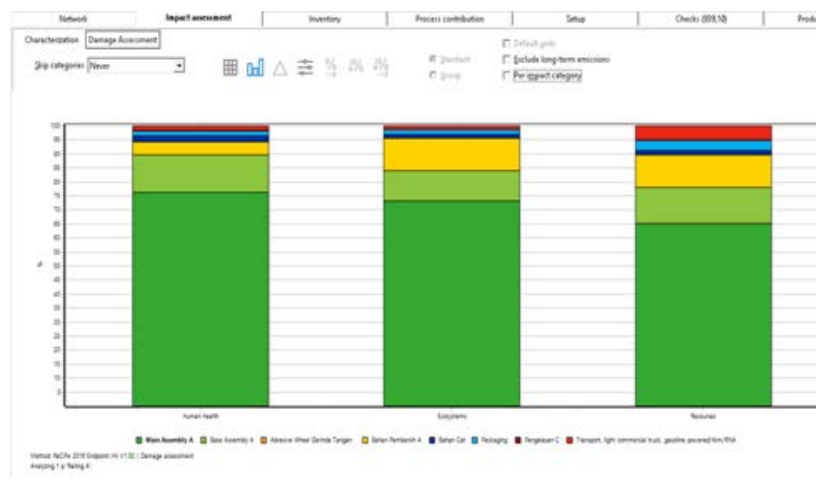

Gambar. 6. Hasil Penilaian Dampak pada Railing A

\section{B. Perbaikan Rancangan Produk dengan Metode DFE}

Dalam perbaikan rancangan produk diterapkan Prinsip DFE yaitu mereduksi dan substitusi material yang memiliki kontribusi tertinggi terhadap dampak lingkungan tanpa mempengaruhi fungi utama dari produk tersebut. Berikut pada gambar 7 adalah rancangan desain produk perbaikan yang dibuat:

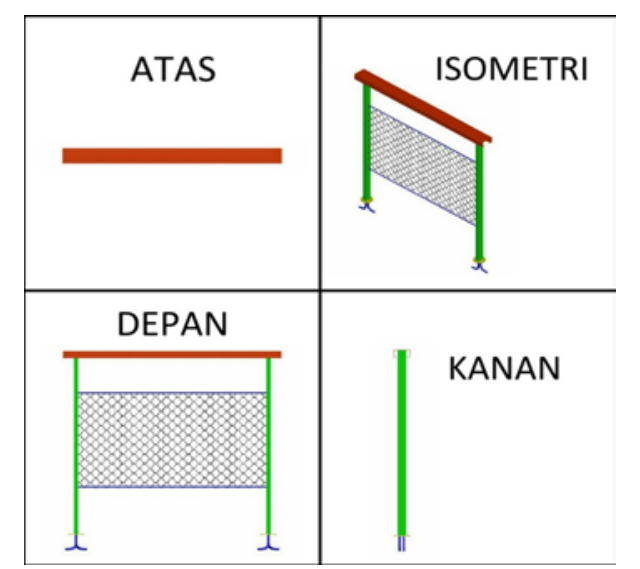

Gambar 7. Desain Rancangan Produk Railing Setelah Perbaikan 


\section{Penilaian Dampak Lingkungan Setelah Perbaikan}

Produk Railing yang telah diperbaiki secara desain disebut sebagai Railing B. Railing B selanjutnya dinilai menggunakan perangkat lunak SimaPro dan didapatkan hasil LCA untuk produk railing B adalah sebesar 3,31 E-5 DALY untuk kategori kesehatan manusia sebesar 9,02 E-8 species.year untuk kategori kerusakan ekosistem, dan sebesar 9,24 E-1 USD 2013 untuk kategori kerusakan sumber daya alam. Hasil lebih detail dapat dilihat melalui gambar 8 berikut ini.

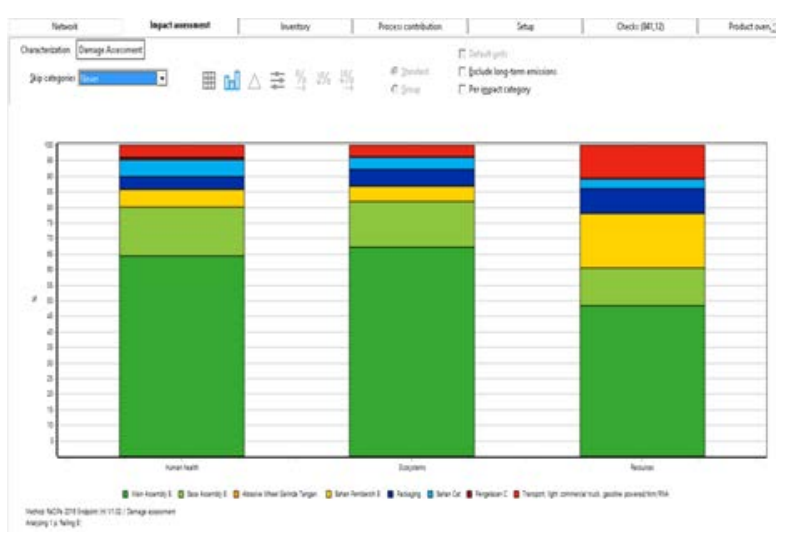

Gambar 8. $\quad$ Hasil Penilaian Dampak pada Railing B

\section{Komparasi Nilai Dampak Lingkungan}

Untuk mengetahui perbedaan dampak lingkungan yang dihasilkan produk railing desain awal dan desain setelah perbaikan maka dilakukan komparasi nilai. Selain itu, komparasi nilai dampak ini bertujuan untuk mengetahui seberapa besar nilai dampak yang tereduksi akibat adanya upaya perbaikan. Komparasi nilai dilakukan menggunakan SimaPro dan didapatkan hasil bahwa produk railing B memiliki dampak lingkungan yang lebih rendah dibandingkan dengan dampak yang dihasilkan oleh produk railing A. Hasil komparasi dapat dilihat pada gambar 9 berikut ini.

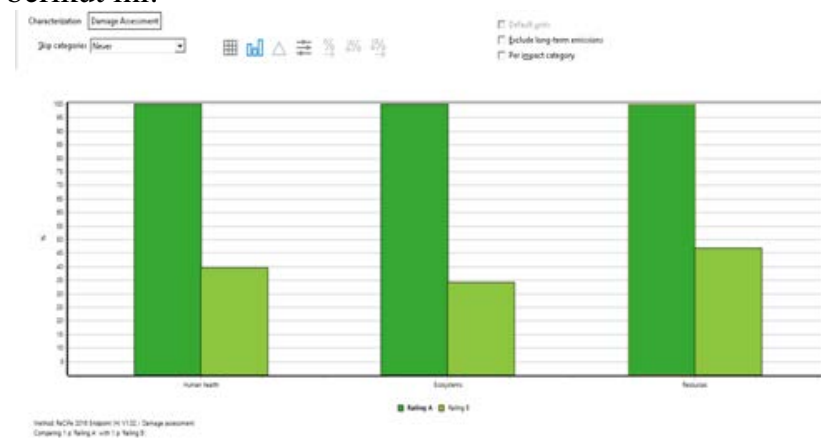

Gambar 9. Hasil Komparasi Nilai Dampak

\section{KESIMPULAN}

Kesimpulan dari penelitian ini didapatkan sebagai berikut:

1. Nilai LCA untuk dampak kesehatan manusia railing A sebesar 8,32 E-5 DALY dan nilai LCA untuk dampak kesehatan manusia railing B sebesar 3,31 E-5 DALY.

2. Nilai LCA untuk dampak kerusakan ekosistem railing A sebesar 2,64 E-7 species.year dan nilai
LCA untuk dampak kerusakan ekosistem railing B sebesar 9,02 E-8 species.year.

3. Nilai LCA untuk dampak kerusakan sumber daya alam railing A sebesar 1,97 USD 2013 dan nilai LCA untuk dampak kerusakan ekosistem railing B sebesar 9,24 E-1 USD 2013.

4. Rancangan produk railing dengan menggunakan metode DFE mampu mereduksi nilai dampak lingkungan. Hasil komparasi antara railing A dan railing B didapatkan selisih nilai rata-rata kerugian lingkungan sebesar 59,74 \% dengan rincian mengurangi dampak lingkungan, dengan rincian 60,2\% untuk dampak kesehatan manusia, 65,8\% untuk dampak ekosistem, dan 53,2\% untuk dampak sumber daya alam.

\section{DAFTAR PUSTAKA}

[1] Simarmata, M.M., Sudarmanto, E., Kato, I., Nainggolan, L.E., Purba, E., Sutrisno, E., Chaerul, M., Faried, A.I., Marzuki, I., Siregar, T. and Sa'ida, I.A., Ekonomi Sumber Daya Alam. Yayasan Kita Menulis. 2021.

[2] Callister Jr, W.D. and Rethwisch, D.G., Fundamentals of materials science and engineering: an integrated approach. John Wiley \& Sons. 2020.

[3] Harjanto, T.R., Fahrurrozi, M., Bendiyasa, I. M., Life Cycle Assessment Pabrik Semen PT Holcim Indonesia Tbk. Pabrik Cilacap: Komparasi antara Bahan Bakar Batubara dengan Biomassa, Jurnal Rekayasa Proses, Vol. 6, No. 2, Universitas Gajah Mada. 2012.

[4] Utina, R., Pemanasan global: dampak dan upaya meminimalisasinya. Dosen Biologi. FMIPA Universitas Negeri Gorontalo. 2009

[5] Finkbeiner, M., Tan, R. and Reginald, M., Life cycle assessment (ISO 14040/44) as basis for environmental declarations and carbon footprint of products. In ISO Technical Committee 207 Workshop, Norway. 2011.

[6] Marzuki, P.F., Abduh, M. and Driejana, R., Peran Life Cycle Analysis (LCA) Pada Material Konstruksi Dalam Upaya Menurunkan Dampak Emisi Karbon Dioksida Pada Efek Gas Rumah Kaca. In Konf. Nas. Tek. Sipil (Vol. 7, pp. 24-26).

[7] Fiksel, J., Design for Environment: A Guide to Sustainable Product Development - Second Edition, United States: The McGraw-Hill Companies, Inc. 2009.

[8] Curran, M. A., Life Cycle Assessment Handbook: A Guide for Environmentally Sustainable Product, Salem: Scrivener Publishing LLC. 2012.

[9] Goedkoop, M., Oele, M., Leijting, J., Ponsioen, T., Meijer, E., Introduction to LCA with SimaPro, Netherlands: Pré. 2016.

[10] Goedkoop, M., Oele, M., Leijting, J., Ponsioen, T., Meijer, E., SimaPro Tutorial, Netherlands: Pré. 2016. 